DOI https://doi.org/10.18551/rjoas.2020-11.15

\title{
COST EFFICIENCY OF INTEGRATED FARMING SYSTEM BASED ON RICE-CATTLE IN BENGKULU PROVINCE OF INDONESIA
}

\author{
Kurniati Novitri* \\ Faculty of Agriculture, University of Muhammadiyah Bengkulu, Indonesia \\ Sukiyono Ketut \\ Faculty of Agriculture, University of Bengkulu, Indonesia \\ Purmini \\ Faculty of Economics and Business, University of Bengkulu, Indonesia \\ *E-mail: novitrikurniati@umb.ac.id
}

\begin{abstract}
Integrated farming system of rice and cattle utilizes cattle and rice waste to be processed into organic fertilizer and feed which will be reused in farming. One of the excellences of integrated farming based on rice and cattle is production cost efficiency. This study aims at analyzing the costs efficiency as well as the variables that affect cost efficiency and inefficiency integrated farming systems in Bengkulu Province, Indonesia. The data taken was primary data on 129 rice and cattle farmers. The data were analyzed by using Stochastic Frontier Cost function. The parameters of the function were estimated by the maximum likelihood method using the computer program Frontier version 4.1. The results of the study showed that the variables of land area, seed prices, wage rates and tiller prices had a significant effect, while the variable price of Nitrogen fertilizer and P fertilizer price does not have a significant effect on the production costs of integrated farming on rice and cattle. Meanwhile, the variable of farmer's age has a significant effect on inefficiency, while the variables of education, rice farming experience and experience of cattle farming have no significant effect on inefficiency.
\end{abstract}

\section{KEY WORDS}

Cost efficiency, integrated farming, rice, cattle.

Agriculture is one of the key strategic sectors in Indonesia, and rice is the most important food crop because rice is the staple food of the Indonesian people. In the recent mid-term five years development plan, Indonesian government attaches importance to food security and plans to achieve the self sufficiency of rice by strengthening rice policy, input subsidy program, and government procurement and reserve (Antriyandarti, 2015). The role of agriculture sector in Bengkulu Province is also adequately strategic where nearly $46,48 \%$ of the productive workforce works in the agricultural sector and this sector redounds $28,14 \%$ in the GDP of Bengkulu Province (BPS, 2019).

Rice farming has become the main source of livelihood for most of the population and has even become part of the culture. Based on the agroecosystem and land suitability, rice plants have great potential and opportunities to be developed in Bengkulu Province with paddy fields of 105,177 ha. Most of the farmers in Bengkulu Province raise cattle and cattle are still a source of income for rural farmers. The high interest in growing cattle is due to natural conditions suitable for livestock cultivation and has been a priority in the development of the livestock sector. The number of cattle population in Bengkulu Province is 115,739 heads (BPS, 2019).

Integrated farming system is farming system intensification through integrated natural and environmental resource management with livestock components as part of business activities. Al Mamun et al., (2011) explained in the integration system there are concepts of minimizing risk, increasing production and income and improving organic waste and plant 
residues. Whereas Soni et al., (2014) explained that the integration system is a mixture of crop and livestock farming, where crop waste is used as animal feed and livestock waste is used as fertilizer to increase soil fertility and processed as fuel. The basis of the integrated farming system is the synergy and complementarity between plants and livestock. In addition, both wastes can be mutually utilized (Manjunatha et al, 2014).

The main characteristic of integrated farming system is the existence of synergism or mutually beneficial relationships between plants and livestock. Cow manure waste is processed into compost and granular organic fertilizer, cow urine liquid waste is taken as liquid fertilizer, while crop waste such as straw, leaves and stems can be processed into animal feed (Soni, et al, 2014; Jaishankar, et al, 2014).

As for the investigation of the cost efficiency of agricultural farming, many studies have been already conducted (Z. Bayramoglu and Gundogmus, 2018; Audu et al., 2013; Nan Jiang, 2014; Tauer and Mishra, 2019; E. Antriyandarti, 2015). In addition, most studies use a production fucntion model for estimating stochastic frontier function. Most of them use the cross sectional data, however if we use frontier function approach, it is more desirable to use the poled data.

Aigner et al., Meeusen and Broeck in Tenaye, A., (2020) introduced a efficiency and inefficiency analysis model in farming that can be identified through a stochastic production frontier function. This approach was introduced more broadly with the relationship between production factors and production in frontier conditions, namely the combination of the use of inputs to produce optimal production. The initial form of the stochastic frontier is a production function whose specifications are for cross-section data and the resulting error term has two components. The first error term is caused by random effects that cannot be controlled by farmers and the other is caused by technical inefficiencies or management factors that can be controlled by farmers as the producers.

Efficiency study has presumed important dimension in agricultural production because sparse resources are integrated to produce outputs. The success of any farm business depends on the ability of the farmer to combine the scarce resources in the true proportion. Cost efficiency is the ability of a farmer to produce the maximum level of output possible at a minimum cost outlay under a given technology. Cost efficiency is resulted from technical efficiency and allocative efficiency. A cost efficient operation results in large profit for the farmer (Siagian and Soetjipto, 2020).

This paper makes two significant contributions. First, to the best of our knowledge, this is the first study that aims to analyze the cost efficiency as well as the factors that affect production costs and inefficiency variables in the integrated farming system based on rice and cattle in Bengkulu. Second, this paper is among of the few studies to measure the cost efficiency of integrated farming by applying a stochastic frontier approach and using a cost function model, which contain a rich poled data of production cost in Bengkulu Province, Indonesia.

\section{METHODS OF RESEARCH}

The sample in this study was taken from the population of farmers who carry out integrated farming based on rice and cattle. The location of the study was chosen purposively in Bengkulu Province, Indonesia. The sampling method employed the Accidental Sampling technique with a minimum sample size of ten times the number of independent variables used in each study area (Roscoe in Sukiyono, 2018). In this study, the number of samples taken was 129 farmers who engaged in integrated farming based on rice and cattle.

To estimate the cost efficiency of integrated farming system, we apply the cost function of the Stochastic Frontier. The word frontier may appropriately apply to each case because the function sets a limit to the range of possible observation. The amount by which a farmer lies below its production frontier and the amount by which it lies above its cost frontier can be regarded as the measures of inefficiency factors such as age, education, etc. The strong point of stochastic frontier analysis comparison with the other analysis is it takes into account measurement errors and other noise in the data (Kumbakhar et al., 2014; Coelli et al., 2005). 
This point is very important for studies of farm households in developing economy like Bengkulu Indonesia as data generally include errors.

The cost function of the Stochastic frontier approach introduced by Aigner et al.; Meeusen and Broek; Coelli et al., in Jiang, N. et al, (2014), which is formulated as follows:

$$
\mathrm{Ci}=\mathrm{g}(\mathrm{Yi}, \mathrm{Pi} ; \alpha)+\varepsilon i \mathrm{i}=1,2,3, . . \mathrm{n}
$$

Where: $\mathrm{Ci}=$ total of production cost; $\mathrm{Yi}=$ output produced; $\mathrm{Pi}=$ input price; $\alpha=$ cost function parameter; $\varepsilon \mathrm{i}=$ error term.

Analysis and cost efficiency measurement is done by deriving the dual cost function from the production function. The method applied is to minimize the input cost function with the production function constraints so that the dual frontier cost function. This study follow the method of estimating a stochastic frontier cost function proposed by Coelli et al., in Antriyandarti (2015) is specified as follows:

$$
\ln B P=\beta_{0}+\beta_{1} \ln L h+\beta_{2} \ln P B n h+\beta_{3} \ln P N+\beta_{4} \ln P P+\beta_{5} \ln P T K+\beta_{6} P A n k+\left(v_{i} \mu_{1}\right)
$$

Where:

In $\mathrm{BP}=$ production costs for integrated rice-cattle $(\mathrm{Rp})$;

In Lh = land area (ha);

In PBnh = price of rice seeds $(\mathrm{Rp} / \mathrm{kg})$;

In $\mathrm{PN}=$ price of fertilizer $\mathrm{N}(\mathrm{Rp} / \mathrm{kg})$;

In $P P=$ price of $P$ fertilizer $(R p / k g)$;

In PTk = labor wages (Rp / HKSP);

In Pank = price of calves (Rp / calf);

$\beta o=$ intercept;

$\beta 1-\beta 7=$ estimator parameter coefficients;

$V i+\mu i=$ error term $(\mu i=$ inefficiency effect in the model).

The value of the distribution parameter $(\mu \mathrm{i})$ of the cost inefficiency effect in this study was formulated as follows:

$$
\mu \mathrm{i}=\delta 0+\delta 1 \mathrm{Um}+\delta 2 \mathrm{Pdk}+\delta 3 \mathrm{PgUT}+\delta 4 \mathrm{PgS}
$$

Where:

$\mu \mathrm{i}=$ cost inefficiency effect;

Um = farmer's age (years);

Pdk = formal education of farmers (years);

PgUT = farming experience (years);

$P G S=$ cattle business experience (years);

$\delta 0=$ intercept;

$\delta 1 \ldots \delta 5=$ estimator parameter coefficient.

Estimating the parameters of the model above uses the method of Maximum Likehood Estimation (MLE) with the Frontier computing program application version 4.1.

\section{RESULTS AND DISCUSSION}

The age of respondent farmers is in productive age group with an average age of 46.51 years. This shows that the majority of farmers still have a strong physique so that they can manage their farming well. Age is also related to the experience and maturity of the farmer in doing farming. The education of respondent farmers is on average junior high school level. Education in general will influence the farmer's mindset. The higher education level of farmers, the easier it is to implement technological innovations.

Initially, almost all respondents were rice farmers, but a few years later they tried to raise cows for fattening. The average rice farming experience is 15 years, while the 
experience of cattle farming is 7.83 years. The area of rice farming is 0.70 hectares and the average cattle ownership by farmers is 4.9 heads.

The labor used mostly comes from within the family. Farmers use superior rice seeds and local varieties of Sintanur and Inpari. Until now, farmers have not been able to ignore the use of chemical fertilizers and pesticides, because the use of organic fertilizers is not sufficient to increase productivity as expected. These organic fertilizers and pesticides are produced by farmers themselves from processing cow feces and urine.

The use of cow feed varies greatly depending on the availability at the research location. The main feed given to cows is grass and rice straw. Then it should be given additional feed such as bran, concentrate and palm oil waste.

The research findings show that rice farming income is IDR 20,020,040/year, while the income of beef cattle is IDR $13,451,690$ /year so that the combined income of the integrated farming is IDR $33,471,730 /$ year. The amount of revenue, cost and income from rice and cattle farming is presented in the Table 1.

Table 1 - Revenue, Cost and Income of Integrated Farming (IDR/Year)

\begin{tabular}{lllll}
\hline No. & Type & Rice Farming & Cattle Farming & Total \\
\hline 1. & Revenue & $33,157,275.00$ & $43,561,150.00$ & $76,718,425.00$ \\
2. & Cost & $13,137,235.00$ & $30,109,460.00$ & $43,246,695.00$ \\
3. & Income & $20,020,040.00$ & $13,451,690.00$ & $33,471,730.00$ \\
\hline
\end{tabular}

Source: Primary Data, 2019.

The estimation results of Cobb-Douglass Frontier Cost Function shown by Table 2. We estimate the Cobb-Douglass frontier cost function with heteroscedasticity. The frontier model allows heteroscedasticity in either error term as a linier function of a set of covariates. We specify covariates for both variance of the Ui and Vi. The component of inefficiency and statistical disturbance term are heteroscedastic (Kumbakhar et al., Greene in Antridayarti, 2015).

The cost efficiency is the possible minimum cost ratio with specific inefficiency level toward actual total cost. The cost efficiency index eU is calculated from the inverse of $\mathrm{eU}=\mathrm{q} / \mathrm{f}(\mathrm{x})$; q: actual cost, $\mathrm{f}(\mathrm{x})$ : cost on the frontier function (Coelli, 2005; in Antriyandarti, 2015). Therefore, the cost efficiency is defined as the percentage achievement of production cost by best practice. Thus, the estimated cost efficiency indices calculated from frontier function.

Table 2 - Estimation of Cobb-Douglass Frontier Cost Function of Integrated Farming

\begin{tabular}{llll}
\hline Variable & Coefficient & Standard Error & $\mathrm{t}-$ Ratio \\
\hline Ln constant $(\beta \mathrm{o})$ & 11.84 & 1.28 & 9.23 \\
Ln Land area $(\beta 1)$ & -0.0008 & 0.00014 & $-6.05^{\star *}$ \\
Ln Price of Seeds $(\beta 2)$ & 0.41 & 0.08 & $4.71^{* *}$ \\
Ln Fertilizer Prices of N $(\beta 3)$ & 0.00008 & 0.00024 & 0.34 \\
Ln Fertilizer Prices of P $(\beta 4)$ & -0.07 & 0.12 & -0.58 \\
Ln Wage TK $(\beta 5)$ & -0.0007 & 0.00041 & $-1.89^{*}$ \\
Ln Price of Calves $(\beta 6)$ & 0.37 & 0.15 & $2.39^{* *}$ \\
\hline Sigma squared $\left(\sigma^{2}\right)$ & 0.77 & 0.25 & $3.00^{* *}$ \\
Gamma (Y) & 0.879 & 0.061 & $14.21^{\star *}$ \\
LR test of the one sided error & & & $14.41^{\star *}$ \\
\hline
\end{tabular}

** Significant at $1 \%$ level, * Significant at 5\% level.

Individual test results on integrated farming systems of rice and cattle reveals that there are four independent variables that statistically significantly affect the production costs of integrated farming. These variables are the area of land, the price of seeds, the level of wages and the price of calves, whereas the variable of Nitrogen fertilizer prices and the $P$ fertilizer price do not have a significant effect on the production cost of the integrated farming system. 
Land area and labor wage variables have a significant effect with marked negative. This indicates that an increase in land area and labor costs will reduce the production costs of integrated farming system. High production will reduce production costs because the ability of farmers to cultivate land in accordance with the inputs used is not excessive. On the other hand, affordable input prices, with the appropriate use will produce output in accordance with the economic sacrifice made by farmers.

In this research, although labors in the family are not paid in real terms, it is still calculated as an implicit cost and is included in the cost of production like explicit cost. Therefore, implicit cost refers to the value of the inputs owned by the farm which is used by the farm in its own production processes. Labors that are used by farmers as well as working on rice and cattle farming. The difference in economic performance which is reflected by the rate of return of production costs in the form of revenue and income as well as the relatively high productivity of labor use is able to avoid the negative effect of the increase in labor wages, so that labor wages have an effect on reducing the production costs of integrated farming based on rice and cattle.

Hanafie (2015) states that the use or allocation of optimum inputs can be sought by looking at the additional value of one unit of revenue (marginal revenue). Farming is said to be efficient if the farming carried out benefits, where the additional output value is greater than the additional input value. Variable of seed price and calf price increase the production cost of integrated farming system. These two variables have a very significant effect with positive marked. Farmers use a variety of rice seeds, where the more expensive the price of rice seeds, the more increase the cost of rice farming production. The price of calf tiller has an effect on increasing the production cost of integrated farming system, and the more expensive the price of calf tiller, the older the age and the heavier weight of the tiller.

This result is in line with research done by Ogundari and Ojo (2007) which states that all factors have significant effect to the cost of Cassava production in Osun state for the variable of seed prices, fertilizer, herbicides and labor costs. Similarly, research done by Audu, S.I., et al., (2013) shows that variable of wage rates, household size and product prices significantly affect the production costs.

The cost of farm production is payment made to inputs employed on the farm. The farmer pay wages to laborers, rent for land, interest for borrowed capital, priced of seed, herbicides, feed, fertilizers and other farm inputs. All this payments are included in his cost of production. The variable of nitrogen fertilizer price that most farmers use urea fertilizer and phosphorus fertilizer prices do not significantly affect the cost of integrated farming. This is cause by some farmers combine the use of chemical fertilizers with compost produced by farmers themselves.

Analysis of the cost inefficiency effect is carried out together with the analysis of cost efficiency by applying the cost function of the stochastic frontier analysis with maximum likelihood estimation (MLE) model. Cost inefficiency was modeled as a truncated normal distribution with the mean as a function of farm characteristics, parameters were estimated simultaneously with those in the stochastic cost frontier by maximum likelihood. Results indicate there is only one independent variable that has a very significant effect on inefficiency, namely the age of farmers, while the other three independent variables are education, the experience of rice farming and the experience of cattle farming does not have significant effect on inefficiency. The results of the cost inefficiencies analysis in integrated farming are presented in table 3.

Table 3 - Variables of Cost Inefficiency in Integrated Farming

\begin{tabular}{llll}
\hline Variable & Coefficient & Standard of Error & $t$ - Ratio \\
\hline Konstanta $(\sigma 0)$ & 7.62 & 6.93 & 1.09 \\
age $(\sigma 1)$ & 0.0079 & 0.0047 & $1.67^{\star}$ \\
education $(\sigma 2)$ & -5.97 & 4.28 & -1.39 \\
Experience in rice farming $(\sigma 3)$ & -0.0055 & 0.0043 & -1.27 \\
Experience in cattle farming $(\sigma 4)$ & 2.96 & 2.11 & 1.40 \\
\hline
\end{tabular}

* Significant at 5\% level. 
The age of farmers has positive effect on inefficiency in integrated farming. These results indicate that increasing the age of farmers will cause farming inefficiency. This is because the older of farmer's age, the less physical and the farmer's management ability to manage the farm. This seemingly can be explained if younger farmers head more adaptable to accept and implement the new innovation technology of integrated farming.

The findings of the study also showed that the variables of education, rice farming experience and cattle farming experience did not significantly affect the farming inefficiency. This means that they are will drive towards the cost efficiency of integrated farming.

A technology or management practice may reduce unit cost of production but only if farmer is efficient implementing the technology or practice. Some farmers may find that the technology or practice does not reduce cost of production as expected because they are inefficient in implementation (Tauer and Mishra, 2019).

In previous studies conducted by Ogundari and Ojo (2007), Nwaru et al (2011), Laha and Kuri (2011), the efficiency for each farmer can be determined by dividing the level of efficiency based on the following criteria very efficient $\geq 0.90$, quite efficient $0,70-0,90$ and not efficient $<0.70$.

The coefficient of cost efficiency in the integrated farming shows that the lowest cost efficiency is 0.25 , and the highest is 0.905 . The average value of cost efficiency is 0.71 . The distribution of cost efficiency outcomes in integrated farming on rice and cattle is presented in Table 4.

Table 4 - Distribution of Cost Efficiency Integrated Farming on Rice and Cattle

\begin{tabular}{lll}
\hline Efficiency Index & Total number & Percentage \\
\hline$<0,70$ & 35 & 27,13 \\
$0,70-0,89$ & 74 & 57,36 \\
$0,90-1,00$ & 20 & 15,50 \\
\hline & 129 & 100 \\
Efficiency rate & 0,71 & - \\
\hline
\end{tabular}

Source: Primary Data, 2019.

Table 4 informs that the integrated farming system farmers are not efficient $(27.13 \%)$, quite efficient $(57.36 \%)$ and very efficient $(15.50 \%)$. While the average efficiency value of 0.71 with the criteria quite efficient. The results of this research in line with Alem H., (2018) which state that in short term, the crop farm in estimating mean cost efficiency scores ranging from $0.53-0.95$ and according to Bayramoglu et al., (2014), in organic farming the average cost efficiency is 0.712 .

The results of this study are supported by research of Kusnadi et al. (2011), on the analysis of the efficiency of rice farming in several rice production centers in Indonesia using the stochastic frontier model Cobb Douglass concluded that rice farming in five provinces of rice production centers in Indonesia have been efficient with an average efficiency of 0.91 .

It's can be explained that integrated farming is efficient because it has several advantages. Besides the main yields of rice and cattle such as livestock can be used as labor, helps improving soil fertility due to continuous planting using compost originating from livestock waste, and crop waste can be used as animal feed. It will reduce production cost which can increase farmer's income.

\section{CONCLUSION}

First, the production cost is significantly influenced by the land rent, seed price, labor wages and calf price. This implies that the reduction of land rent, seed price, labor wages and calf price are more effective in decreasing the production cost of integrated farming.

Second, the age farmers have a significant effect on the cost inefficiency. This implies that the older of farmer's age, the less physical and the farmer's management ability to manage the farm. 
Third, the results of efficiency analysis shows that average cost efficiency 0.71 is in the criteria of being quite efficient. This results indicating that integrated farming can reduce cost production. Thus, the estimation results are mostly plausible and consistent with the theory.

\section{REFERENCES}

1. Alem, H. 2018. Effect of Model Specification, Short-Run and Long-Run Inefficiency an Empirical Analysis of Stochastic Frontier Models. Agric. Econ. - 64. 2018 (11): 508-516.

2. Al Mamun, S. Fouzia, N., 2011. Integrated Farming System: Prospects in Bangladesh. Journal Environment Science and Natural Resources, 4(2): 127 - 136, 2011.

3. Antriyandarti, Ernoiz., 2015. Competitiveness and Cost Efficiency of Rice Farming in Indonesia. Journal of Rural Problems 51 (2): $74-85$.

4. Audu, S.I., Otitolaiye, J.O., and Ibitoye, S.J., 2013. A Stochastic Frontier Approach to Measurement of Cost Efficiency in Small Scale Cassava Production in Kogi State Nigeria. European Scientific Journal. March 2013 Edition, Volume 9 No. 9. P: 114 -130.

5. Bayramoglu, Z. and E. Gundogmus. 2014. Cost Efficiency on Organic Farming: A Comparison between Organic and Conventional Raisin-Producing Households in Turkey. Spanish Journal of Agricultural Research. 6(1): 3-11.

6. Biro Pusat Statistik. 2019. Bengkulu Dalam Angka. Bengkulu.

7. Hanafie, R., 2015. Pola Konsumsi Pangan Pokok Rumahtangga Pedesaan. Journal of Social and Agricultural Economics, 4 (2). P: 1-7.

8. Jaishankar, N.B., S. Janagoudar, Basavaraj, K., Vasudev, P.N. and Siddayya, S. 2014. Integrated Farming for Sustainable Agriculture and Livelihood Security to Rural Poor. International Conference on Chemical, Biological and Environmental Science. May 1213. Kuala Lumpur. Malaysia.

9. Jiang, N. and Sharp, B., 2014. Cost Efficiency of Dairy Farming in New Zealand, A Stochastic Frontier Analysis. Agriculture and Economic Review, Vol: 43, Issue 3. Des 2014. Cambridge University Press. pp $406-418$.

10. Kumbakhar S.C., Lien G., 2014. Technical Efficiency in Competing Panel Data Models: A Study of Norwegian Grain Farming. Journal of Productivity Analysis 41: 321-337.

11. Kusnadi, Nunung, Netti Tinaprilla, Sri Hery Susilowati dan Adreng Purwoto. 2011. Analisa Efisiensi Usahatani Padi di beberapa Sentra Produksi Padi di Indonesia. Jurnal Agro Ekonomi. Pusat Sosial Ekonomi dan Kebijakan Pertanian. Bogor. 29 (1): 25 - 48.

12. Laha, A. and Kuri, P.K., 2011. Measurement of Allocative Efficiency in Agriculture and It's Determinants: Evidence From Rural West Bengal India. International Journal of Agriculture Research 6 (5): 377 - 388.

13. Manjunatha, S.B., Shivmurthy, D., Sunil, A.S., Nagaraj, M.V., and Basavesha, K.N., 2014. Integrated Farming Systems - An Holistic Approach: A Review. Journal of Agriculture and Allied Sciences. Volume 3. Issue 4.

14. Nwaru, J.C., B. Okoye and P.C. Ndukwu. 2011. Measurement and Determinants of Production Efficiency among Small Holder Sweet Potato Farmers in Imo State. Nigeria. European Journal of Scientific Research. 59 (3): 307-317.

15. Ogundari, K. and S.O. Ojo. 2007. An Examination of Technical, Economic and Allocative Efficiency of Small Farm, The Case Study of Cassava Farmers in Osun State of Nigeria. Journal Central European Agriculture. 7(3): 423-432.

16. Siagian, R.A., 2020. Cost Efficiency of Rice Farming in Indonesia: Stochastic Frontier Approach. Agricultural Socio-Economics Journal. Volume XX (1): 7-14.

17. Soni, R.P., Mittu, K., 2014. Integrated Farming Systems - A Reviev. IOSR Journal of Agriculture and Veterinary Science. Volume 7, Issue 10 Ver. I, PP $36-42$.

18. Sukiyono, Ketut, 2018. Penelitian Survai dan Teknik Sampling. Badan Penerbitan Fakultas Pertanian UNIB. Bengkulu. Indonesia.

19. Tauer, L.W. and Mishra A.K., 2016. Dairy Farm Cost Efficiency. Journal of Dairy Science. Volume 89. Issue 12: 4937-4943.

20. Tenaye, A., 2020. Technical Efficiency of Smallholder Agriculture in Developing Country: The Case of Ethiopia. Journal Economies 8, 34. 